\title{
A Note on Citations
}

All citations from Nietzsche's writings and correspondence are noted parenthetically in the text according to the standards established in current Nietzsche scholarship. Abbreviations used in this study are given below.

When there is no indication in the text, parenthetical citations for published and unpublished writings will include the abbreviation for the work, an indication of where in the work the citation occurs, and the volume and page number in the critical edition. Letters will include the addressee or sender, the date of the letter, the number of the letter, and the volume and page number in the critical edition.

I have consulted various sources for translations, modifying for the sake of accuracy and consistency. In cases where no translation exists, I translated myself.

\section{Editions Used}

BAW Beck'sche Ausgabe Werke = Nietzsche, Friedrich. Historisch-kritische Gesamtausgabe. Werke. 5 vols. Munich: Beck 1933-42.

KGW Kritische Gesamtausgabe der Werke = Nietzsche, Friedrich. Werke. Kritische Gesamtausgabe. Planned ca. 50 vols. Ed. Giorgio Colli, Mazzino Montinari et al. Berlin: de Gruyter, 1967- .

KGB Kritische Gesamtausgabe Briefwechsel $=$ Nietzsche, Friedrich. Briefwechsel. Kritische Gesamtausgabe. 24 vols. Ed. Giorgio Colli, Mazzino Montinari et al. Berlin: de Gruyter, 1975-2004.

KSA Kritische Studienausgabe $=$ Nietzsche, Friedrich. Sämtliche Werke. Kritische Studienausgabe. 15 vols. Ed. Giorgio Colli and Mazzino Montinari. Berlin: de Gruyter, 1980.

KSB Kritische Studienausgabe Briefe $=$ Nietzsche, Friedrich. Sämtliche Briefe. Kritische Studienausgabe. 8 vols. Ed. Giorgio Colli and Mazzino Montinari. Berlin: de Gruyter, 1986.

\section{Published Works}

SGT Sokrates und die griechische Tragoedie [Socrates and Greek Tragedy]

GT Die Geburt der Tragödie [The Birth of Tragedy] 
NJ Ein Neujahrswort [A Message for the New Year]

MD Mahnruf an die Deutschen [Admonition to the Germans]

UB Unzeitgemässe Betrachtungen [Untimely Meditations]

DS David Strauß, der Bekenner und der Schriftsteller [David Strauß, the Confessor and the Writer]

HL Vom Nutzen und Nachtheil der Historie für das Leben [On the Advantage and Disadvantage of History for Life ]

SE Schopenhauer als Erzieher [Schopenhauer as Educator]

WB Richard Wagner in Bayreuth [Richard Wagner in Bayreuth]

MA Menschliches, Allzumenschliches (I und II) [Human, All Too Human]

VM Vermischte Meinungen und Sprüche [Mixed Opinions and Sayings]

WS Der Wanderer und sein Schatten [The Wanderer and His Shadow]

M Morgenröthe [Dawn]

IM Idyllen aus Messina [Idylls from Messina]

FW Die fröhliche Wissenschaft [The Gay Science]

Za Also sprach Zarathustra [Thus Spoke Zarathustra]

JGB Jenseits von Gut und Böse [Beyond Good and Evil]

GM Zur Genealogie der Moral [On the Genealogy of Morals]

WA Der Fall Wagner [The Case of Wagner]

GD Götzen-Dämmerung [Twilight of the Idols]

AC Der Antichrist [The Antichrist]

EH Ecce homo

NW Nietzsche contra Wagner

DD Dionysos-Dithyramben [Dionysian Dithyrambs]

\section{Unpublished Writings and Fragments}

Nachlass Nachlass [Literary Remains]

WM Die Nachlass-Kompilation “Der Wille zur Macht” [The Compilation from the Literary Remains "The Will to Power"]

GMD Das griechische Musikdrama [The Greek Music Drama]

ST Socrates und die Tragödie [Socrates and Tragedy]

DW Die dionysische Weltanschauung [The Dionysian Worldview]

GG Die Geburt des tragischen Gedankens [The Birth of Tragic Thought]

BA Ueber die Zukunft unserer Bildungsanstalten [On the Future of Our Educational Institutions]

CV Fünf Vorreden zu fünf ungeschriebenen Büchern [Five Prefaces to Five Unwritten Books] 
PHG Die Philosophie im tragischen Zeitalter der Griechen [Philosophy in the Tragic Age of the Greeks]

WL Ueber Wahrheit und Lüge im aussermoralischen Sinne [On Truth and Lies in an Extramoral Sense] 
This page intentionally left blank 